\title{
POLA DISTRIBUSI DAN KOMPOSISI GASTROPODA PADA RESORT KUCUR TN ALAS PURWO
}

\section{DISTRIBUTION PATTERN AND COMPOSITION OF GASTROPODS ON THE KUCUR RESORT TN ALAS PURWO}

\author{
Fuad Ardiyansyah \\ Universitas PGRI Banyuwangi \\ Email: fuad.unibabwi.ac.id
}

\begin{abstract}
ABSTRAK
Gastropoda pada Resort Kucur selain sebagai dekomposer juga berfungsi sebagai indikator stabilitas lingkungan. Tujuan pada penelitian ini untuk mengetahui pola distribusi dan komposisi gastropoda yang berada di Resort Kucur Taman Nasional Alas Purwo. Metode yang digunakan adalah purposive sampling, terbagi menjadi 3 stasiun dengan jarak antar stasiun sejauh $1 \mathrm{~km}$ dengan jarak antar transek $30 \mathrm{~m}$ dan pada setiap garis transek diletakkan plot berukuran $2 \times 2 \mathrm{~m}^{2}$ dengan jarak antar plot $10 \mathrm{~m}$. Hasil komposisi gastropoda pada Resort Kucur yang ditemukan berjumlah 5 famili, 6 genus, dan 10 spesies yang terdiri atas famili Potamididae, Muricidae, Neritiidae, Littorinidae, Cerithiidae dengan genus yang terdiri atas Terebralia, Ceritidea, Chicoreus, Nerita, Littoraria, Cerithium dan spesies Terebralia sulcata, Cerithidea cingulata, $C$. quardrata, Chicoreus capucinus, Nerita undata, N. balteata, Littoraria scabra, L. angulifera, L. carinifera, Cerithium coralium. Hasil indeks keanekaragaman pada tiap stasiun menunjukkan $\mathrm{H}^{\prime}=<1$ yang menunjukkan bahwa keanekaragaman jenis tergolong rendah. Kepadatan tertinggi dari Nerita undata dengan nilai kepadatan berkisar antara 150-332 $\mathrm{ind} / \mathrm{m}^{2}$. Pola sebaran distribusi gastropoda di tiap stasiun bersifat mengelompok.
\end{abstract}

Kata kunci: Komposisi, Distribusi, Gastropoda, Resort Kucur

\begin{abstract}
Gastropods in Kucur Resort besides as decomposers also function as indicators of environmental stability. The purpose of this study was to determine the distribution patterns and composition of gastropods in Kucur Resort Alas Purwo National Park. The method used is purposive sampling divided into 3 stations with the distance between stations as far as $1 \mathrm{~km}$ with the distance between transects $30 \mathrm{~m}$ and on each transect line is placed a plot measuring $2 \times 2 \mathrm{~m}^{2}$ with a distance between plots $10 \mathrm{~m}$. The results of gastropod compositions in Resort Kucur were found to be 5 families, 6 genera, and 10 species consists of family Potamididae, Muricidae, Neritidae, Littorina, Cerithidea with genus consists of Terebralia, Ceritidea, Chicoreus, Nerita, Littoraria, Cerithium and species Terebralia sulcata, Cerithidea cingulata, C. quardrata, Chicoreus capucinus, Nerita undata, N. balteata, Littoraria scabra, L. angulifera, L. carinifera, Cerithium coralium. The result of index diversity in each station shows $\mathrm{H}^{\prime}=<1$ that species diversity is low. The highest density of Nerita undata with density values ranges from $150-332 \mathrm{ind} / \mathrm{m}^{2}$. Distribution patterns of gastropods in each station are clumped.
\end{abstract}

Keywords: Distribution, Composition, Gastropods, Resort Kucur 


\section{PENDAHULUAN}

Wilayah pesisir merupakan wilayah peralihan air tawar dengan asin yang ditempati beragam ekosistem. Hutan mangrove merupakan salah satu ekosistem pada wilayah interface sebagai wilayah peralihan air tawar dan air asin. Secara ekologi hutan mangrove berperan sebagai nutrient pool terhadap ketersediaan detritus organik, yang sangat penting bagi sumber energi biota yang hidup di perairan sekitar. Gastropoda merupakan salah satu organisme yang tinggal di ekosistem hutan mangrove yang memanfaatkan substrat yang terdapat di hutan mangrove sebagai sumber makanan. Pada hal ini menjadikan gastropoda berasosiasi dengan ekosisitem mangrove sebagai habitat hidup, berlindung, memijah, dan juga sebagai suplai makanannya. Potamididae merupakan jenis gastropoda asli pada hutan mangrove yang hidup pada zona intertidal dan berkedudukan sebagai dekomposer yang berperan penting dalam proses dekomposisi serasah serta mineralisasi materi organik. Secara umum gastropoda berperan sebagai siklus hara dengan cara memanfaatkan serasah mangrove dan juga sebagai rantai makanan pada tropik level kedua. Oleh karenanya gastropoda pada tingkat trofik terbagi menjadi detrifor, herbifor, dan karnifor (Rusnaningsih, 2012; Cappenberg et al, 2006).

Gastropoda pada umumnya peka terhadap perubahan lingkungan akibat kontaminan dan kelimpahannya dipengaruhi oleh kontaminan bahan anorganik (Sirante, 2011). Perubahan kualitas perairan tersebut dapat berpengaruh terhadap komposisi dan keragaman populasi dari satu organisme. Oleh karena itu, keberadaan organisme tersebut pada ekosistem mangrove dapat berfungsi sebagai indikator stabilitas lingkungan yang mengalami gangguan pencemaran utamanya daerah perairan (Choubisa et al, 2013).

Kelimpahan dan distribusi gastropoda juga dipengaruhi oleh faktor lingkungan setempat seperti ketersediaan pakanan, pemangsaan dan kompetisi hidup. Hal tersebut dikarenakan tiap hewan gastropoda memiliki kemampuan yang berbeda-beda ditiap individu. Bervariasinya faktor lingkungan menyebabkan adanya perbedaan cara hidup dan penyebaran dari gastropoda tersebut.

Hutan mangrove yang berada di Resort Kucur masih masuk dalam kawasan Teluk Pangpang Taman Nasional Alas Purwo, Secara struktural kawasan hutan 
mangrove di Resort Kucur Taman Nasional Alas Purwo tergolong alami, meskipun di sebelah Barat luar area Taman Nasional Alas Purwo area hutan mangrovenya telah mengalami alih fungsi untuk kegiatan tambak. Secara global, adanya limbah tambak yang masuk kedalam ekosistem mangrove terlalu banyak dan tidak dapat diproses untuk didaur ulang akan mempengaruhi pertumbuhan dari hutan mangrove yang pada akhirnya akan mempengaruhi organisme yang hidup di dalamnya.

\section{METODE}

Penelitian dilakukan pada bulan Maret-Mei 2017 di wilayah Resort Kucur Taman Nasional Alas Purwo. Metode pengumpulan data menggunakan purposive sampling, yang dilakukan pada tiga stasiun pengamatan di Teluk Pangpang. Pada bagian utara berbatasan dengan Tanjung Sembulungan, di bagian selatan berbatasn dengan Resort Jati Papak, di bagian barat berbatasan dengan Kecamatan Tegaldlimo, dan pada bagian timur berbatasan dengan Tanjung Weringinan. Pada masing-masing stasiun ditarik sejajar dengan garis pantai pada vegetasi terluar sampai kedalam hutan mangrove. Jarak antar stasiun sejauh $1 \mathrm{~km}$, dengan jarak antar transek $30 \mathrm{~m}$ dan pada setiap garis transek diletakkan plot berukuran $2 \times 2 \mathrm{~m}^{2}$ dengan jarak antar plot $10 \mathrm{~m}$. Gastopoda yang diamati meliputi tree fauna, infauna dan epifauna. Untuk pengambilan sampel jenis gastropoda infauna dilakukan penggalian sedalam $10 \mathrm{~cm}$ (Netto dan Gallucci, 2003) gastropoda jenis epifauna dan tree fauna (akar, batang, dan daun mangrove) di dalam plot langsung dikoleksi dengan tangan, sedangkan sampel tree fauna diambil sampai dengan ketinggian 1,5 m sampai batas pasang tertinggi.

Analisis data berupa analisis indeks keanekaragaman, kepadatan gastropoda, kepadatan relatif, dan pola distribusi gastropoda.

Indeks keanekaragaman $\left(\mathrm{H}^{\prime}\right)$ dihitung dengan menggunakan indeks ShannonWiener, berikut:

$$
\mathrm{H}^{s}=-\Sigma p i \ln p i
$$

Keterangan: $\mathrm{H}^{\prime}=$ indeks keanekaragaman Shannon-Wiener

$\mathrm{Pi}=$ peluang kepentingan untuk tiap jenis $(\mathrm{ni} / \mathrm{N})$

$\mathrm{ni}=$ nilai kepentingan tiap jenis (jumlah individu tiap jenis)

$\mathrm{N}=$ nilai kepentingan total (jumlah total semua individu) 
Perlu (1991), menyatakan bahwa indeks keanekaragaman $\left(\mathrm{H}^{\prime}\right)$ terdiri dari beberapa kriteria, yaitu:

$$
\begin{array}{ll}
\mathrm{H}>3,0 & =\text { keanekaragaman sangat tinggi } \\
1,6 \leq \mathrm{H} \leq 3,0 & =\text { keanekaragaman tinggi } \\
1,0 \leq \mathrm{H} \leq 1,5 & =\text { keanekaragaman sedang } \\
\mathrm{H} \leq 1 & =\text { keanekaragaman rendah }
\end{array}
$$

Kepadatan Gastropoda dihitung dengan menggunakan rumus berikut:

$$
\mathrm{Di}=\frac{\mathrm{ni}}{\mathrm{A}}
$$

Keterangan: Di: kepadatan individu jenis ke-i

ni: jumlah individu jenis ke-i

A: luas kotak pengambilan sampel

Indeks dispersi (Id) dihitung dengan menggunakan rumus Morisita sebagai mengukur persebaran tiap individu.

$$
\mathrm{Id}=\mathrm{n}\left[\frac{\Sigma \mathrm{xi}^{2}-\Sigma \mathrm{x}}{(\Sigma \mathrm{x})^{2}-\Sigma \mathrm{x}}\right]
$$

Keterangan: $\mathrm{Id}=$ indeks penyebaran Morisita

$$
\begin{aligned}
\mathrm{n} & =\text { jumlah unit pengambilan sampel } \\
\mathrm{xi} & =\text { jumlah individu setiap petak sampel } \\
\mathrm{x} & =\text { jumlah indvidu total yang diproleh }
\end{aligned}
$$

Kriteria: $\quad$ Id $<1=$ penyebaran spesies seragam

$\mathrm{Id}=1=$ penyebaran spesies acak

Id $>1=$ penyebaran kelompok

\section{HASIL DAN PEMBAHASAN}

Berdasarkan hasil penelitian komposisi jenis gastropoda yang ditemukan pada Resort Kucur Taman Nasional Alas Purwo berjumlah 5 famili, 6 genus, dan 10 spesies yang terdiri atas famili Potamididae, Muricidae, Neritiidae, Littorinidae, Cerithiidae 
dengan genus yang terdiri atas Terebralia, Ceritidea, Chicoreus, Nerita, Littoraria, Cerithium dan spesies Terebralia sulcata, Cerithidea cingulata, C. quardrata, Chicoreus capucinus, Nerita undata, N. balteata, Littoraria scabra, L. angulifera, L. carinifera, Cerithium coralium. Sepuluh gastropoda yang ditemukan dikelompokkan menjadi tiga kelompok yaitu gastropoda asli mangrove, gastropoda fakultatif dan gastropoda pendatang (Budiman, 1991). Dari gastropoda yang didapatkan seperti jenis Terebralia sulcata, Cerithidea cingulata, C. quardrata, Chicoreus capucinus merupakan Gastropoda asli mangrove yang frekuensi dan kelimpahannya berada pada hutan mangrove. Fitriana (2006) menambahkan dari jenis Gastropoda asli mangrove selain pemakan serasah, juga terdapat beberapa jenis tergolong predator. Poutiers (1998) menjelaskan jenis gastropoda predator yang ditemukan di hutan mangrove dari kelompok Muricidae. Dalam hal ini jenis Gastropoda dari kelompok Muricidae yang ditemukan adalah Chicoreus capucinus.

Gastropoda pengunjung yang didapatkan adalah dari jenis Nerita undata, N. balteata. Gastropoda dari kelompok pengunjung sebagian besar pemakan alga dan fitoplankton yang secara frekuensi dan kelimpahan diluar hutan mangrove jauh lebih tinggi dibandingkan di dalam ekosistem hutan mangrove (Budiman, 1991). Tan dan Clements (2008) menambahkan famili Neritidae lebih banyak berada pada luar hutan mangrove karene famili Neritidae merupakan Gastropoda air tawar. Sedangkan untuk Gastropoda fakultatif yang ditemukan terdiri jenis Littoraria scabra, L. angulifera, L. carinifera, Cerithium coralium. Ke empat jenis Gastropoda yang ditemukan merupakan jenis pemakan mikroflora yang ada di kulit kayu dan daun-daun mangrove (Rusnaningsih, 2012; Ayunda, 2011). Tapilatu dan Pelasula (2012) menambakan bahwa biota penempel pada hutan mangrove banyak didominasi oleh suku Littorinidae. 
Jurnal Biologi dan Pembelajaran Biologi

(p-ISSN 2527-7111; e-ISSN 2528-1615)
Volume 3 Nomor 2 Tahun 2018

http://jurnal.unmuhjember.ac.id/index.php/BIOMA

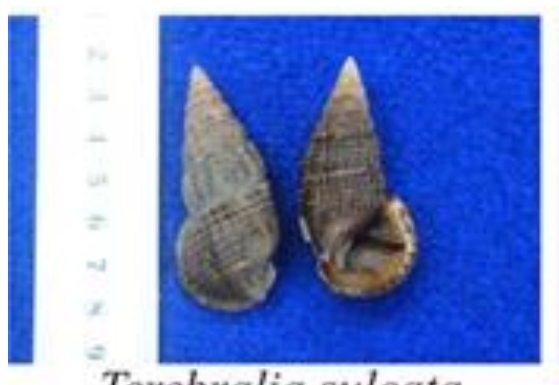

Terebralia sulcata

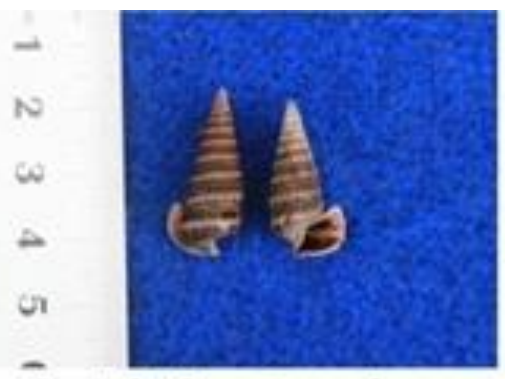

$\bar{C}$ erithidea cingulata

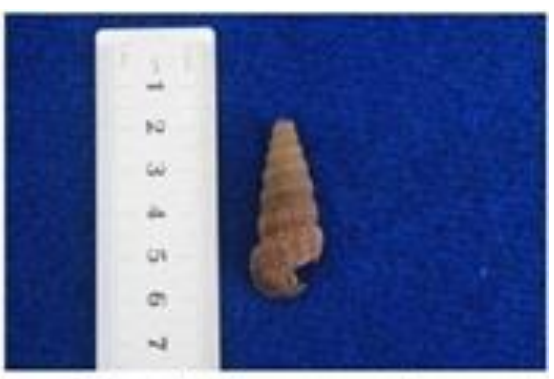

Cerithidea quadrata

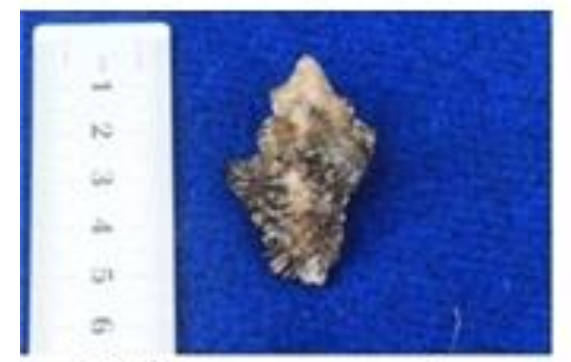

Chicoreus capucinus

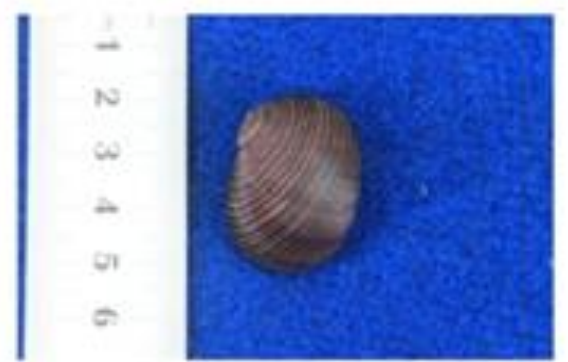

Nerita balteata

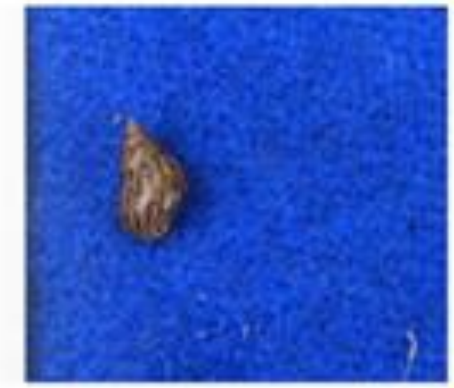

Littorina scabra

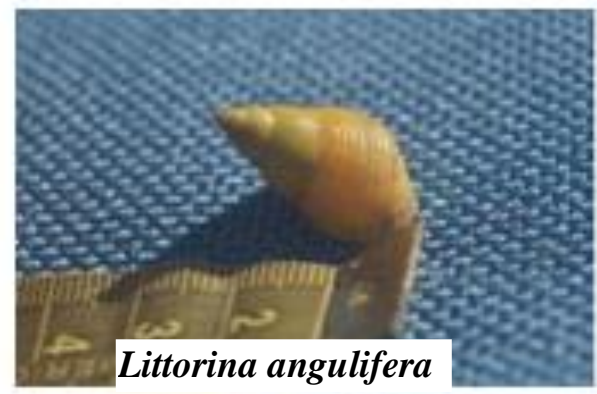

Littorina angulifera
Nerita undata

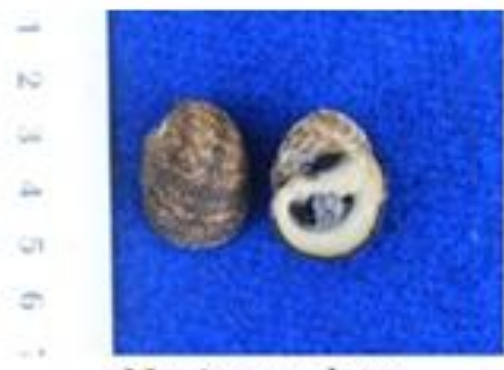

$\infty$

Littorina carinifera

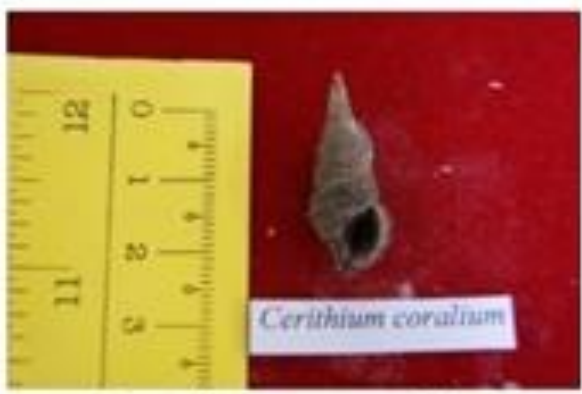

\section{Cerithium coralium}

Gamber 1. Jenis-jenis Gastropoda yang ditemukan di Resort Kucur Teluk Pangpang Taman Nasional Alas Purwo 
Secara keseluruhan nilai indeks keanekaragaman gastropoda pada tiap stasiun tergolong rendah. Rentangan nilai tersebut berkisar antara $H^{\prime}=0,35-0,37$. Keanekaragaman terendah terlihat pada stasiun 2 yang dapat dilihat pada Tabel 1. Di bawah ini.

Tabel 1. Keanekaragaman Jenis Gastropoda Pada Resort Kucur TNAP

\begin{tabular}{ccc}
\hline Stasiun & Indeks Keanekaragaman & Makna \\
\hline 1 & 0,37 & Rendah \\
\hline 2 & 0,35 & Rendah \\
\hline 3 & 0,37 & Rendah \\
\hline
\end{tabular}

Keterangan: $\mathrm{H}^{\prime} \leq 1=$ Keanekaragaman rendah

Berdasarkan hasil analisis data indeks keanekaragaman pada tiap stasiun di Resort Kucur menunjukkan $\mathrm{H}^{\prime}=<1$ yang menunjukkan bahwa keanekaragaman jenis tergolong rendah. Kondisi ini menunjukkan bahwa keanekaragaman pada stasiun tergolong miskin dan adanya indikasi tekanan yang menjadikan ekosistem tidak stabil. Purnama (2011) menambahkan indeks keanekaragaman $H^{\prime}=<1$ menandakan bahwa produktivitasnya sangat rendah. Ewusie (1980) menjelaskan bahwa bentuk rendahnya suatu keanekaragaman menunjukkan keadaan stres dari sistem atau salah satu sistem mengalami penurunan, karna adanya sebuah pencemaran. Hal tersebut sesuai dengan lokasi penelitian sebelah Barat yang mana berbatasan dengan Kecamat Tegaldlimo telah banyak vegetasi mangrove beralih fungsi menjadi area pertambakan. Vairamani (2008), menjelaskan kerusakan habitat akibat kegiatan alih fungsi dari vegetasi mangrove menjadi area pertambakan dapat mempengaruhi keanekaagaman jenis suatu wilayah.

Kecilnya indeks keanekaragaman pada Resort Kucur $\mathrm{H}^{\prime}=<1$ juga disebabkan adanya suatu komunitas gastropoda yang mendominasi pada kawasan tersebut. Menurut Soegianto (1994) suatu komunitas tidak akan memiliki nilai indeks keanekaragaman yang tinggi apabila dalam komunitas tersebut terdapat satu atau lebih jenis yang 
dominansinya mencolok. Begitupula sebaliknya, nilai indeks keanekaragaman akan menjadi besar apabila populasi yang satu dengan yang lain sangat umum sedangkan yang lainnya jarang. Dengan jumlah individu yang jarang, sangat menentukan jumlah dari keanekaragaman jenis, dengan kata lain nilai keanekaragaman jenis cenderung akan rendah apabila adanya beberapa kelompok jenis-jenis Gastropoda yang memiliki populasi rendah. Rendahnya jumlah populasi Gastropoda dan variasi jumlah individu tiap spesies menunjukkan keadaan tersebut terjadi ketidakseimbangan ekosistem yang disebabkan gangguan atau tekanan dari lingkungan. Keadaan ini menjelaskan bahwa hanya jenis spesies tertentu saja yang dapat bertahan hidup. Tidak meratanya jumlah individu untuk tiap spesies berhubungan dengan pola adaptasi tiap gastropoda, seperti tersedianya berbagai tipe substrat, makanan, dan kondisi lingkungan (Saptarini et al., 2010).

Tabel 2. Kepadatan dan Kepadatan Relatif Pada Resort Kucur TNAP

\begin{tabular}{|c|c|c|c|c|c|c|c|}
\hline \multirow{2}{*}{ No } & \multirow{2}{*}{ Spesies } & \multicolumn{3}{|c|}{$\begin{array}{l}\text { Kepadatan tiap stasiun } \\
\qquad\left(\mathrm{ind} / \mathrm{m}^{2}\right)\end{array}$} & \multicolumn{3}{|c|}{ Kepadatan relatif $(\%)$} \\
\hline & & $\begin{array}{c}\text { Stasiun } \\
1\end{array}$ & $\begin{array}{c}\text { Stasiun } \\
2\end{array}$ & $\begin{array}{c}\text { Stasiun } \\
3\end{array}$ & $\begin{array}{c}\text { Stasiun } \\
1\end{array}$ & $\begin{array}{c}\text { Stasiun } \\
2\end{array}$ & $\begin{array}{c}\text { Stasiun } \\
\quad 3\end{array}$ \\
\hline 1 & $\begin{array}{l}\text { Littoraria } \\
\text { caranifera }\end{array}$ & 10 & 4 & 0 & 7,40 & 2,60 & 0,00 \\
\hline 2 & Nerita undata & 268 & 150 & 332 & 3,60 & 2,00 & 4,40 \\
\hline 3 & Littorina scabra & 76 & 28 & 70 & 4,40 & 1,60 & 4,00 \\
\hline 4 & $\begin{array}{l}\text { Littorina } \\
\text { angulifera }\end{array}$ & 1 & 0 & 0 & 10,00 & 0,00 & 0,00 \\
\hline 5 & $\begin{array}{l}\text { Terebralia } \\
\text { sulcata }\end{array}$ & 76 & 32 & 42 & 5,10 & 2,10 & 2,80 \\
\hline 6 & $\begin{array}{l}\text { Cerithidea } \\
\text { cingulata }\end{array}$ & 4 & 7 & 91 & 0,40 & 0,60 & 9,00 \\
\hline 7 & Nerita balteata & 40 & 50 & 0 & 4,40 & 5,60 & 0,00 \\
\hline
\end{tabular}




\begin{tabular}{cccccccc}
\hline 8 & $\begin{array}{l}\text { Cerithidea } \\
\text { quardrata }\end{array}$ & 6 & 0 & 0 & 10,00 & 0,00 & 0,00 \\
\hline $9 \begin{array}{l}\text { Chicoreus } \\
\text { capucinus }\end{array}$ & 38 & 40 & 54 & 2,90 & 3,00 & 4,10 \\
\hline 10 & $\begin{array}{l}\text { Cerithium } \\
\text { coralium }\end{array}$ & 7 & 57 & 1 & 1,00 & 8,90 & 0,10 \\
\hline Jumlah individu & 526 & 368 & 590 & 49,20 & 26,40 & 24,40 \\
\hline & 10 & 8 & 6 & & & \\
\hline
\end{tabular}

Dari hasil analisis data (Tabel 2) menunjukkan kepadatan gastropoda pada Resort Kucur berkisar pada stasiun 1 berkisar antara $1-268 \mathrm{ind} / \mathrm{m}^{2}$, stasiun 2 berkisar $4-150 \mathrm{ind} / \mathrm{m}^{2}$, stasiun 3 berkisar 1$331 \mathrm{ind} / \mathrm{m}^{2}$. Jika diambil nilai rata-rata dari total jumlah kepdatan spesies sebesar $494,7 \mathrm{ind} / \mathrm{m}^{2}$. Dari nilai kepadatan tersebut dilaporkan Syaffitri (2003) yang pernah dilakukan penelitian serupa didapatkan nilai kepadatan $229 \mathrm{ind} / \mathrm{m}^{2}$. Hal ini menunjukkan bahwa kepadatan spesies gastropoda di Resort Kucur tergolong padat. Sedangkan kepadatan relatif jenis gastropoda di stasiun 1 berkisar 1,00-10,00\%, stasiun 2 berkisar 1,60-8,90\%, sedangkan stasiun 3 berkisar 0,10-9,00\%.

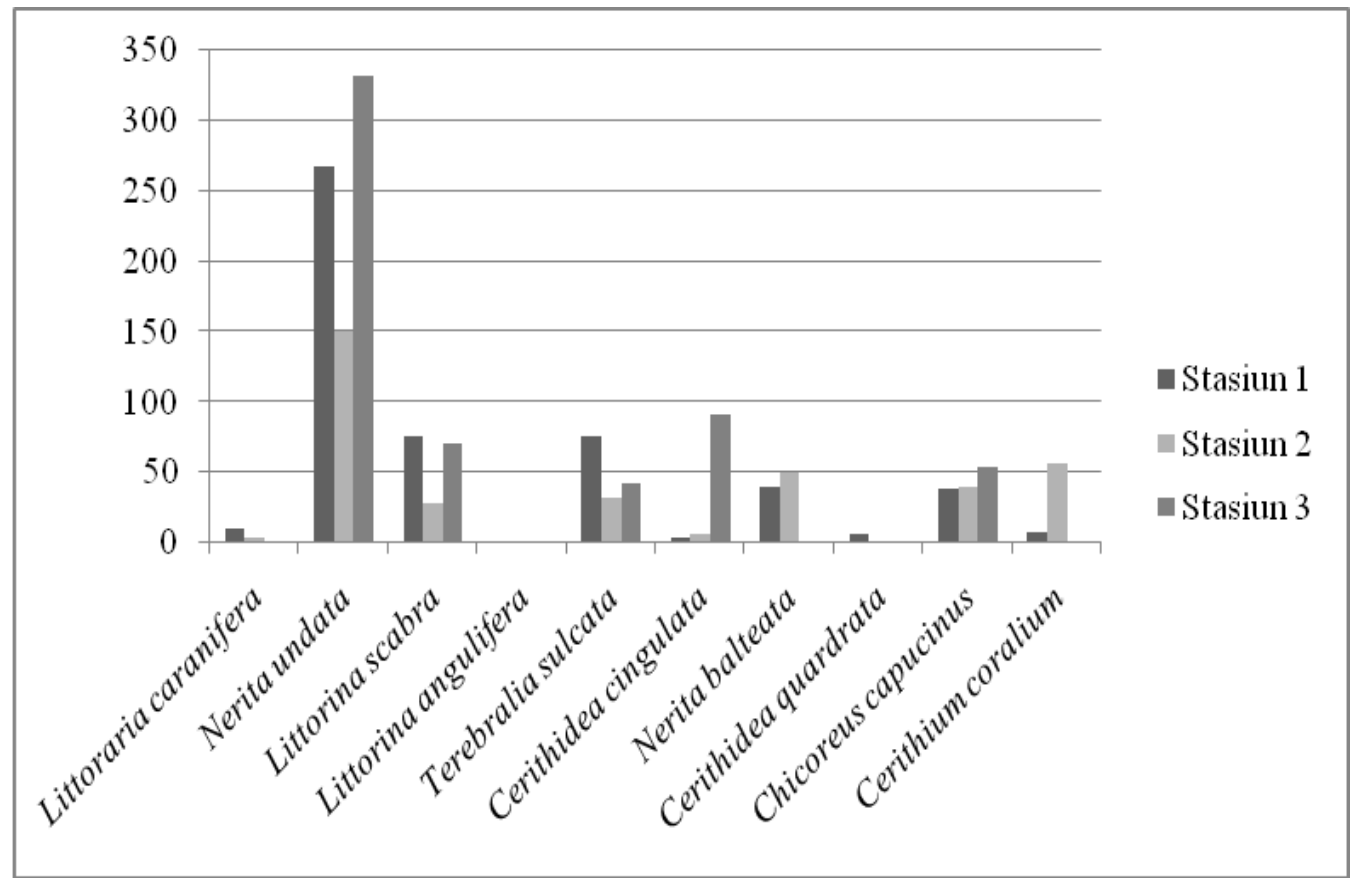

Gambar 2. Grafik jumlah kepadatan gastropoda pada tiap stasiun 
Diketahui bahwa Nerita undata merupakan jenis gastropoda yang memiliki nilai kepadatan tertinggi dari pada jenis gastropoda yang lain yakni berkisar antara $150-332 \mathrm{ind} / \mathrm{m}^{2} \mathrm{dan}$ dari jenis ini didapatkan di tiap-tiap stasiun. Berdasarkan hasil tinjauan di lapangan, perairan hutan mangrove pada Resort Kucur selalu tergenang, sehingga pada lokasi tersebut jarang detemukan gastropoda asli mangrove utamanya dari kelompok Potamididae. Pada kondisi wilayah mangrove paling depan (pionir) yang selalu tergenang oleh air, akan menjadikan organisme pengunjung dalam hal ini Nerita undata banyak ditemukan di wilayah tersebut. Nerita undata dapat beradaptasi dengan cara bergerak aktif naik turun mengikuti pasang surut, sehingga Nerita undata dapat beradaptasi terhadap perubahan lingkungan yang disebabkan oleh pengaruh pasang surut. Supriharyono (2007) menjelaskan bahwa kuat arus dari pasang surut dapat mempengaruhi sebaran dan juga perpindahan dari suatu tempat ke tempat lain di perairan. Budiman (1991), menambahkan Nerita undata merupakan gastropoda pengunjung yang secara tidak sengaja berada di dalam hutan mangrove. Hal ini yang menjadikan frekuensi dan kelimpahan Nerita undata di luar hutan jauh lebih tinggi dibandingkan di dalam ekosistem hutan mangrove. Terlebih lagi Nerita undata memiliki toleransi serta dapat memanfaatkan daerah yang tercemar sebagai tempat memperoleh makan (Kamalia, 2013). Oleh sebab itu Nerita undata banyak ditemukan ditiap stasiun.

Tabel 3. Pola sebaran distribusi gastropoda di Tiap Stasiun

\begin{tabular}{lcccc}
\hline No & Lokasi Penelitian & Jumlah & Chi square & Pola Sebaran \\
\hline 1 & Stasiun 1 & 725 & 1606,63 & Mengelompok \\
\hline 2 & Stasiun 2 & 507 & 665,04 & Mengelompok \\
\hline 3 & Stasiun 3 & 813 & 2218,60 & Mengelompok \\
\hline
\end{tabular}

Pada Tabel 3 pola sebaran distribusi gastropoda pada stasiun 1-3 menunjukkan sama-sama pola sebaran secara mengelompok. Pola sebaran mengelompok tersebut berkaitan erat dengan beberapa faktor seperti kondisi lingkungan, tipe substrat, kebiasaan makan dan reproduksi (Budiman, 1991). Bahri Fuad, Pola Distribusi 
(2006) menyatakan pola distribusi suatu biota dipengaruhi oleh tipe habitat yang meliputi faktor fisika-kimia perairan serta makanan dan kemampuan adaptasi dari suatu biota dalam ekosistem.

Tabel 4. Kondisi Fisika Kimia pada masing-masing stasiun

\begin{tabular}{ccccc}
\hline No & Parameter & Stasiun 1 & Stasiun 2 & Stasiun 3 \\
\hline 1 & Jenis Substrat & Liat, pasir & Liat, pasir & Liat, pasir \\
\hline 2 & Suhu $\left({ }^{\circ} \mathrm{C}\right)$ & 23 & 23 & 21 \\
\hline 3 & pH tanah & 7 & 7 & 7 \\
\hline
\end{tabular}

Dari hasil pengukuran suhu yang dilakukan di semua stasiun penelitian berkisar antara $21-23^{\circ} \mathrm{C}$. Suhu terendah didapatkan pada stasiun 3 sedangkan suhu tertinggi didapatkan pada stasiun 2 dan 3. Secara keseluruhan rentangan suhu tersebut masih tergolong normal akan tetapi jika suhu lebih dari $40^{\circ} \mathrm{C}$ dapat mempengaruhi perkembangan dan reproduksi bahkan kematian (Prashar et al, 1983). Nilai pH tanah pada Resort Kucur tergolong netral $(\mathrm{pH}=7)$. Kondisi $\mathrm{pH}=7$ tersebut menunjukkan bahwa faktor kimia pada subtrat mangrove sesuai dengan kehidupan gastropoda. Hutabarat dan Evans (1985) menambahkan perubahan pada tinggi rendahnya nilai pH akan memberikan pengaruh terhadap reproduksi gastropoda yang secara umum kondisi $\mathrm{pH}$ 6,5-8,5 berpengaruh terhadap kelangsungan hidup dan reproduksi gastropoda tersebut. Jenis Substrat yang didapatkan pada tiap stasiun relatif liat berpasir. Umumnya gastropoda menyukai daerah berlumpur karena partikel organik yang halus dengan kandungan organik yang tinggi dapat mensuplai nutrien dan air yang diperlukan untuk kelangsungan hidupnya (Nybaken, 1992).

\section{KESIMPULAN DAN SARAN}

Pola sebaran distribusi pada hutan mangrove Resort Kucur bersifat mengelompok dan komposisi jenis spesies yang mendiami pada huta mangrove tersebut dari jenis Terebralia sulcata, Cerithidea cingulata, C. quardrata, Chicoreus capucinus, 
Nerita undata, N. balteata, Littoraria scabra, L. angulifera, L. carinifera, Cerithium coralium.

Bagi penelitian serupa, diharapkan pengambilan sampel sejauh $>2 \mathrm{~km}$ dari garis pantai, mengingat bahwasanya zonasi tumbuhan utama penyusun vegetasi hutan mangrove Resort Kucur $<2 \mathrm{~km}$ masih dalam zonasi garis pantai sehingga cenderung tergenang. Hal ini menjadikan penghuni asli dari famili Potamididae jarang ditemukan.

\section{DAFTAR PUSTAKA}

Ayunda R. 2011. Struktur Komunitas Gastropoda pada Ekosistem Mangrove di Gugus Pulai Pari, Kepulauan Seribu. Skripsi. Universitas Indonesia. Depok.

Budiman, A. 1991. Penelaahan beberapa Gatra Ekologi Moluska Bakau Indonesia. Desertasi. Fakultas Pasca Sarjana Universitas Indonesia. Jakarta.

Cappenberg, H. A. W. 2006. Pengamatan Komunitas Moluska di Perairan Kepulauan Derawan, Kalimantan Timur. Jurnal Oseonologi dan Limnologi Indonesia No. 39.

Choubisa SL. Zulfiya S. 2013. Freshwater Snails (Mollusca: Gastropoda) As Bioindicators For Diverse Ecological Aquatic Habitat. Cibtech Journal of Zoology 2(3), 22-26.

Ewusie, J. Y. 1992. Element of Tropical Ecology. New Hampshire: Heinemann Educational Bokks Ltd.

Fitriana YR. 2006. Keanekaragaman danKemelimpahan Makrozoobentos di Hutan Mangrove Hasil Rehabilitasi Taman Hutan Raya Ngurah Rai Bali. Biodiversitas 7(1), 67-72.

Hutabarat, S., Evans. S. M. 1985. Pengantar Oseanografi. Universitas Indonesia: Jakarta.

Kamalia, M. 2013. Pola Sebaran Gastropoda di Ekosistem Mangrove Kelurahan Tanjung Ayun Sakti Kecamatan Bukit Bestari Kota Tanjung Pinang. Skripsi. Universitas Maritim Raja Ali Haji

Netto, S. A dan Galluci, F. 2003. Meiofauna and macrofauna communities in a mangrove from the Island of Santa Catarina, South Brazil. Journal Hydrobiologia 500, 159-170. 
Poutiers JM. 1998. The Living Marine Resources of The Western Central Pacific. FAO Species Identification Guide for Fishery Purposes 1(4), 363-648.

Purnama PR., Nastiti NW., Agustin ME., Affandi M. 2011. Diversitas Gastropoda di Sungai Sukamade Taman Nasional Meru Betiri Jawa Timur. Jurnal Panel Hayati 16, 143-147.

Rusnaningsih. 2012. Struktur Komunitas Gastropoda dan Strudi Populasi Cerithidea obtusadi Hutan Mangrove Pangkal Babu Kabupaten Tanjung Jabung Barat Jambi. Tesis. Program Studi Biologi Fakultas Matematika dan Ilmu Pengetahuan Alam. Universitas Indonesia.

Rusnaningsih. 2012. Struktur Komunitas Gastropoda dan Studi Populasi Cerithidea Obtusa (Lamarck 1822) di Hutan Mangrove Pangkal Babu Kabupaten Tanjung Jabung Barat, Jambi. Tesis. Universitas Indonesia.

Soegianto, 1994, Ekologi Kuantitatif Metode Analisis Populasi dan Komunitas, Surabaya: Penerbit Usaha Nasional.

Supriharyono. 2007. Konservasi Ekosistem Sumber Daya Hayati. Yogyakarta: Pustaka Pelajar.

Tapilatu Y dan Pelasula D. 2012. Biota Penempel yang Berasosiasi dengan Mangrove di Teluk Ambon Bagian Dalam. Jurnal Ilmu dan Teknologi Kelautan Tropis 4(2), 267-279. 